\title{
仮設足場用養生シートの色による内部空間の改善†
}

$\begin{array}{lll}\text { 伊藤 } & \text { 洋介* } & \text { 河辺 } \\ \text { 高間 } & \text { 健太** } \\ & \text { 浦田 } & \text { 匡真*** }\end{array}$

\section{Improvement of Internal Space by Color of Curing Sheet for Temporary Scaffolding}

\author{
by
}

\author{
Yosuke Iтo*, Shinji KawaBE*, \\ Kenta TAKAMA** and Masanao URATA $* * *$
}

\begin{abstract}
At Construction sites, curing sheets for temporary scaffolding is used to prevent the building materials from falling and dust from scattering. In this study, it was confirmed that by using the curing sheet whose inside is black with good transparency and whose outside is white that can keep the internal temperature low, it is possible to realize an environment with good transparency from the internal space and a low temperature in the internal space. Within the measurement range of this study, the white-and-black curing sheet has a lower internal temperature than the black and gray curing sheets, but the internal temperature is higher than that of the white curing sheet. Further, the white-and-black curing sheet has good transparency like the black curing sheet, and has better transparency than the white and gray curing sheets. The white-and-black curing sheet has a small change in the feeling of the internal space before and after the curing sheet is installed.
\end{abstract}

\section{Key words:}

Curing sheet, Temperature, Transparency, Landolt ring, Landscape

\section{1 緒訔}

近年, 人口・世帯数の減少に伴うマンションの新規供 給戸数は減少傾向にある.一方でマンションストック戸 数は年々増加している ${ }^{1)}$. マンションは竣工後, 定期的 な修繥工事が必要とされること, そして今後, バブル期 に建てられたマンションが大規模修繥のタイミングを 迎えていくことから, 既存建物の修繥工事の需要が増え ていくことが予想されている.

修繥工事の現場では建築資材の落下や粉塵等の飛散 を防ぐため, メッシュの仮設足場用養生シート（以下， 養生シートとする）が使用される。養生シートは色や目 の大きさ, 素材, 強度が様々で, 現場の環境や工事の内 容により使い分けられる. かつては Fig.1(A)に示すよう なグレーの養生シートが一般的であった。しかし，グレ 一の養生シートは工事現場の内部から外部へ向けての 透視性が悪いため, 工事期間中建物内で生活する人々に 対して圧迫感を与える要因となる可能性がある. そのた め, 近年ではグレ一の養生シートに比べて透視性が良く, 開放的に感じる, Fig.1(B)に示寸ような黒色の養生シー トが多くの現場で使用されている.

既往の研究 2)-5)では空面に使用されるブラインドやロ ールスクリーン等の日射遮へい装置の透視性や室内の
感じ方について検討されている，しかし，養生シートの 透視性や養生シート内部の空間 (以下, 内部空間とする) の感じ方については検討されていない.

著者ら のは養生シートの色が内部空間の温度（以下， 内部温度とする）に与える影響について検討した。これ により, 黒色の養生シートを使用した場合は, 白色の養 生シートを使用した場合に比べて内部温度が高くなる ことが明らかになった. 内部温度が高くなると, 夏場に おいて, 居住者や作業員の熱中症リスクが高まるなどの 問題点が考えられる7).
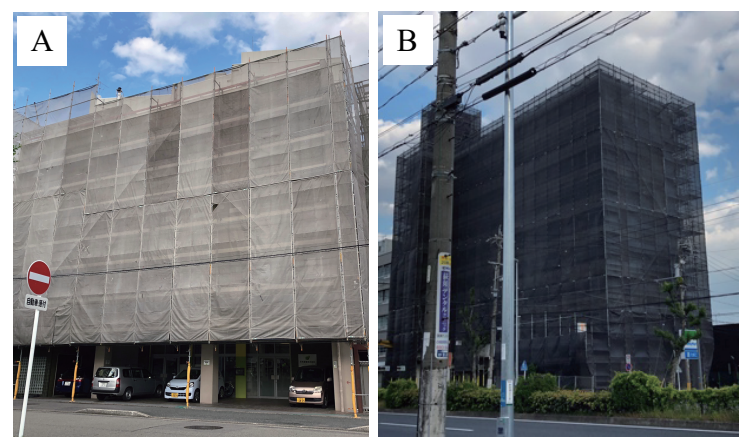

Fig.1 Construction sites using (A) gray curing sheets and (B) black curing sheets.

$\dagger$ 原稿受理 令和 3 年 1 月 8 日 Received Jan.8,2021 @2021 The Society of Materials Science, Japan

* 正会員 名古屋工業大学大学院 工学研究科 $\overline{1} 466-8555$ 名古屋市昭和区御器所町

Graduate School of Engineering, Nagoya Institute of Technology, Syowa-ku, Nagoya 466-8555.

** 名古屋工業大学 工学部 $=466-8555$ 名古屋市昭和区御器所町

Faculty of Engineering, Nagoya Institute of Technology, Syowa-ku, Nagoya 466-8555

*** 建装工業(株) $\bar{\top} 105-0003$ 東京都港区西新橋

KENSO KOGYO CO.LTD., Minato-ku, Tokyo, 105-0003. 
ここで, 内側が透視性の良い黒色，外側が内部温度を 低く抑えられる白色の養生シート（以下，白黒の養生シ 一トとする）を用いることで，透視性が良く，内部温度 の低い環境を実現できると考える。

本研究では，一般的に用いられる白色，グレー，黒色 の養生シートと白黒の養生シートを使用して, 内部温度 の測定と, 透視性と内部空間の感じ方の官能評価を行う. これにより, 白黒の養生シートの使用で養生シート内部 の環境改善が行えるかについて検討する.

\section{2 養生シート}

養生シートは, 修繥工事の現場で用いられているポリ エステルを塩化ビニルで被覆した， 2 類メッシュシート (平岡繊染 (株) ターポスクリーン \#2039) を使用する. 当該養生シートは厚さ $0.4 \mathrm{~mm}$, 充実率 0.580 , 原糸の太 さ $500 \mathrm{~d}$ (デニール), 縦系 20 本 $/ 2.54 \mathrm{~cm}$, 横糸 19 本 $12.54 \mathrm{~cm}$ である。

養生シートの色は一般的に使用される白，グレー，黒 の 3 種類と, 白の養生シートの片面にインクジェット印 刷機で黒の塗装を施した白黒の養生シートの計 4 種類と する。各養生シートの SCI 方式によるマンセル值を Table1 に示す. 測定の際, 白黒の養生シートは内部空間 側が黒色，外部空間側が白色となるように設置する.

\section{$3 \cdot 1$ 測定装置}

\section{3 養生シート内部の温度の測定 ${ }^{6)}$}

測定装置を Fig.2 に示す．養生シートが施工された内 部空間を再現するために, 試験箱を製作する. 試験箱は, 上方一面に開口を持ち横置きに設置したもの（以下，横 置き試験箱とする）と，上方と側方の二面に開口を持ち 縦置きに設置したもの（以下，縦置き試験箱とする）の 2 種類を使用寸る. 2 種類の試験箱は内寸 $400 \mathrm{~mm}$ (W) $\times 400 \mathrm{~mm}(\mathrm{D}) \times 100 \mathrm{~mm}(\mathrm{H})$ とし，測定中に地熱等の影響 を防ぐため，試験箱は断熱材（スタイロフォーム）を用 いて作製し，日光の反射・拡散を防ぐため，試験箱の表 面を黒色のフェルトで覆う.

温度測定には, データロガーと $\mathrm{Cu}-\mathrm{Co}$ 熱電対を用いる. 熱電対の測定部の位置は横置き試験箱の場合，底面の中 央から約 $50 \mathrm{~mm}$ 上方に設置し，他端をデータロガーに接 続する．縦置き試験箱の場合，底面の中央から約 $200 \mathrm{~mm}$ 上方に設置し, 他端をデータロガーに接続する. 養生シ 一トは，横置き試験箱の場合，一面の開口部を覆うよう に設置し，縦置き試験箱の場合，二面の開口部を覆うよ うに養生シートを設置する。養生シートは，四隅に画鋲 を打ち，試験箱に固定する.

\section{$3 \cdot 2$ 測定条件}

測定場所は，測定中，常に日射があたる名古屋工業大 学 24 号館の屋上とする。測定日は 2020 年 9 月 30 日 10:30 15:00 の間, 1 分毎に試験箱内部の温度と気温のデ 一タを記録する. 測定の様子を Fig.3に示す.

\section{4 養生シートの透視性と内部空間の感じ方の測定} $4 \cdot 1$ 測定装置
Table1 Munsell color of the curing sheets.

\begin{tabular}{|c|c|}
\hline Color of the Curing Sheets & Munsell color \\
\hline White & $1.6 \mathrm{GY} 9.2 / 0.4$ \\
\hline Gray & $1.5 \mathrm{GY} 5.2 / 0.2$ \\
\hline Black & $5.7 \mathrm{~PB} 2.3 / 0.2$ \\
\hline White/Black(White) & $0.5 \mathrm{~PB} 8.0 / 0.7$ \\
\hline White/Black(Black) & $8.7 \mathrm{RP} 2.7 / 0.2$ \\
\hline
\end{tabular}

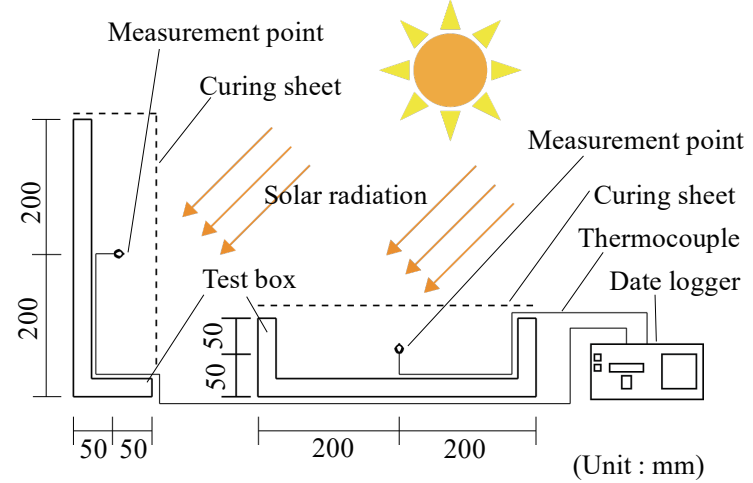

Fig.2 Measuring device for the internal temperature.

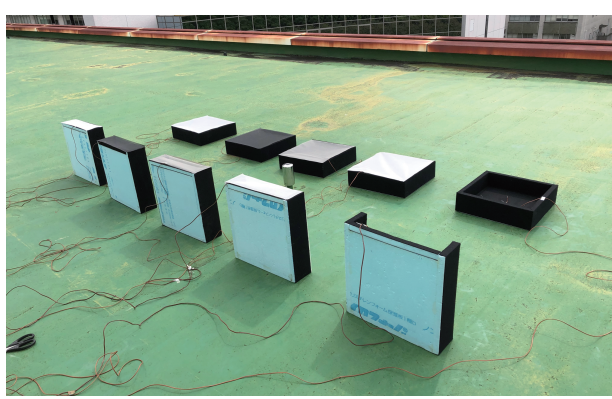

Fig.3 Photograph of the measuring devices for the internal temperature.

養生シートで覆われた内部空間から透視性と内部空 間の感じ方を評価するために, 被験者が入れる大きさで 測定装置を製作する．測定装置を Fig.4 に示す．測定装 置は枠組みを幅 $40 \mathrm{~mm}$ の鉄製フレームで製作し，寸法は $1200 \mathrm{~mm}(\mathrm{~W}) \times 2500 \mathrm{~mm}(\mathrm{D}) \times 1800 \mathrm{~mm}(\mathrm{H})$ とする，底 面と被験者の背面には鉄製フレームに木製パネルを設 置し，照明の反射による影響を防ぐために内面を黒色の フェルトで覆う。養生シートは鉄製フレームに上から被 せ，被験者の前面は養生シートがシワにならないように 磁石で固定する.

被験者は内部に置かれた椅子に腰掛け, 養生シート越 しに $2500 \mathrm{~mm}$ 離れた視対象（視力検查表と景観写真）を 見る. 測定装置の写真を Fig. 5 に示す.

\section{$4 \cdot 2$ 視力検査表を用いた透視性の測定 ${ }^{8)}$}

視力検査で一般的に使用されるランドルト環の視力 検査表を用いて透視性を評価する.ランドルト環の視力 検査は Fig.6 に示すように, 認識できる切れ目の最小の 大きさの視角 MAR (minimum angle of resolution) で表し, その逆数を視力評価值としている．この評価值は単純に 
視角の逆数に相当するため, そのまま統計処理を用いて 評価できない，そのため，式(1)に示すように測定される 視力評価值の逆数の対数変換をした LogMAR を用いる.

$$
\operatorname{LogMAR}=\log _{10}(1 / \text { 視力評価值 })
$$

養生シートをかける前の測定結果を $\log M A R_{1}$ とし, 養 生シートをかけた後の測定結果を $\operatorname{LogMAR} 2$ として, 式 (2)を LogMAR 低下值として評価する.

$$
\log M A R \text { 低下值 }=\operatorname{LogMAR}_{1}-\operatorname{LogMAR}_{2}
$$

一般的な視力検査では検査表から $5000 \mathrm{~mm}$ 離れた位置 で測定を行うが，測定する部屋の大きさを考慮し $2500 \mathrm{~mm}$ の位置から測定するものとし,検査表は $2500 \mathrm{~mm}$ 用に作成したものを使用する。

検查表は通常の背景が白色，ランドルト環が黒色の検 査表（以下，検査表(1)とする）と検査表の色と養生シー 卜の色が重なり見えにくいことが考えられるため, 背景 の白色とランドルト環の黒色を反転させた検査表（以下， 検査表(2)とする) も使用する。また検査表(1)と検査表(2) は無彩色であるため, 有彩色についても考慮し, 背景が 白色, ランドルト環が色の 3 原色のマゼンタ, シアン, イエローの検查表 (以下, それぞれ検査表(3), 検査表(4), 検査表(5)とする) を作成し，計 5 種類の検査表で測定を 行う.

\section{$4 \cdot 3$ 景観写真を用いた透視性の測定 ${ }^{9}$}

実際の養生シートの施工現場で想定される景観で養 生シートの透視性の測定を行うため, 有彩色の景観写真 を用いて透視性を評価する。景観写真は Fig.7(A)に示す, 都会の街並夕が印刷された人工景観写真と Fig.7(B)に示 す,街路樹が印刷された自然景観写真の 2 種類とする. 使 用する景観写真のサイズは掃き出し空のサイズを想定 し, $1700 \mathrm{~mm}(\mathrm{~W}) \times 1800 \mathrm{~mm}(\mathrm{H})$ とする.

人工景観写真では全体の見やすさ，左側のビルの見や すさ, 空の見やすさの 3 項目を評価し, 自然景観写真で は，全体の見やすさ，下側の草木の見やすさ，空の見や すさの 3 項目を評価する．評価方法はすべて，見やすさ について 7 段階評定尺度法で行う.

\section{$4 \cdot 4$ 内部空間の感じ方の測定 ${ }^{10)}$}

養生シートの内部空間の感じ方について, <開放感 $>$ $<$ 温冷感 $><$ 明るさ $><$ 快不快感 $>の 4$ 項目を評価する. これらは各々,養生シートの内部空間について「開放的と 感じるか,閉鎖的と感じるか」，「暖かいと感じるか,冷た いと感じるか」，「明るいと感じるか,暗いと感じるか」， 「快適と感じるか,不快と感じるか」という感じ方である. 評価は 7 段階評定尺度法で行う。

\section{5 測定条件}

一定の環境下で測定を行うため，測定場所は名古屋工 業大学の人工気候室とする. 測定は人工気候室の A 室で

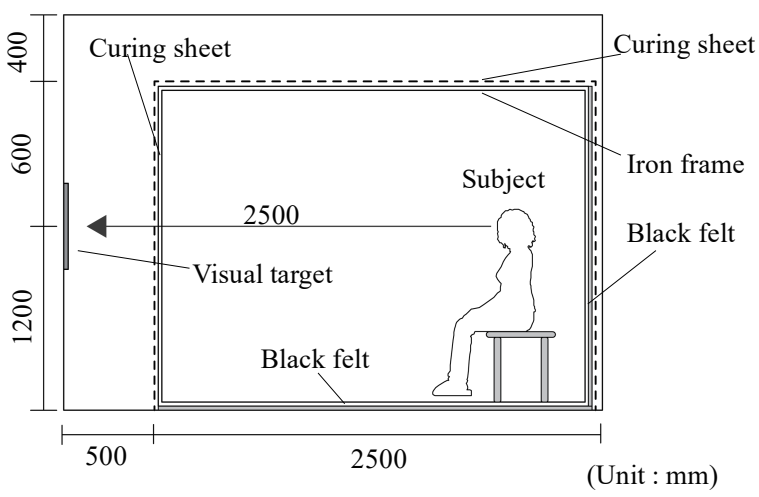

Fig.4 Measuring device for transparency and how to feel the internal space.

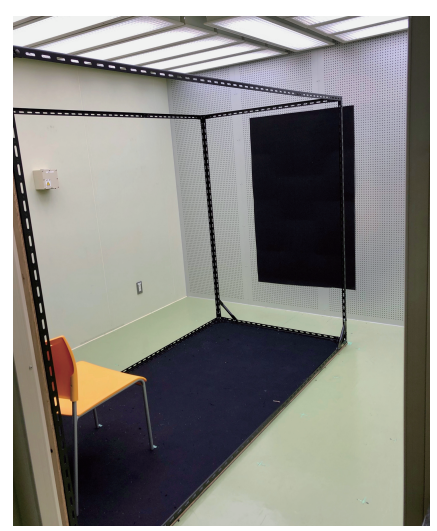

Fig.5 Photograph of the measuring device for transparency and how to feel the internal space.

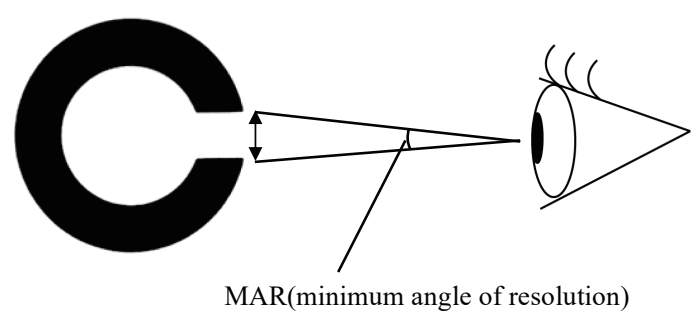

Fig.6 Eye test method using the Landolt ring.
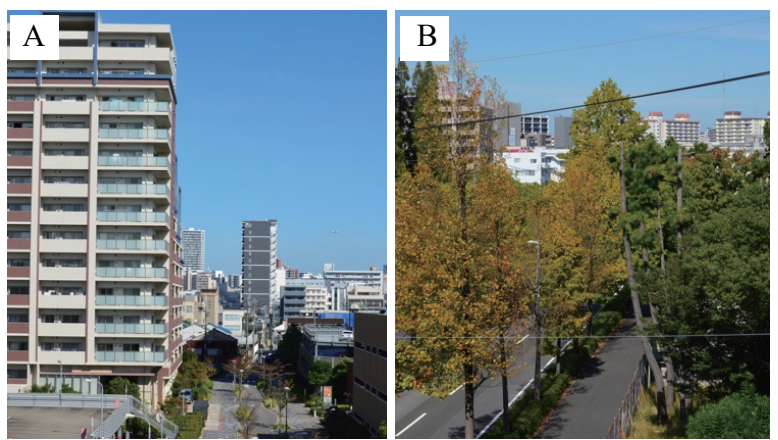

Fig.7 (A) Artificial landscape photo and (B) Natural landscape photo.

行い. 測定の前には B 室で待機する.

測定時における人工気候室の条件を Table 2 に示す. A 室は調光と調色を行うことができ, 照度, 色温度, 温度, 湿 度をほぼ一定に保つことができる. B 室は温度,湿度をほ ぼ一定に保つことができる. 
Table2 Environment of the artificial climate room.

\begin{tabular}{|c|c|c|}
\hline & Room A & Room B \\
\hline Illuminance & $5959(1 \mathrm{x})$ & $1152(\mathrm{~lx})$ \\
\hline $\begin{array}{c}\text { Color } \\
\text { temperature }\end{array}$ & $4850(\mathrm{~K})$ & $4533(\mathrm{~K})$ \\
\hline CRI & 81.3 & 79.5 \\
\hline Temperature & $26\left({ }^{\circ} \mathrm{C}\right)$ & $26\left({ }^{\circ} \mathrm{C}\right)$ \\
\hline Humidity & $55(\%)$ & $55(\%)$ \\
\hline
\end{tabular}

被験者の性別と年齢を Table3 に示寸. 4 ·2 節の測定を 2020 年 10 月 12 日，13 日の 2 日間に行った。被験者は 20 代から 60 代の男女計 33 名であった。 $4 \cdot 3$ 節，4.4 節 の測定を 2020 年 11 月 4 日，5 日の 2 日間に行った。被 験者は 20 代から 60 代の男女計 29 名であった.被験者は 両眼視力が 0.6 以上で, 色覚などの異常がない人とした.

\section{5 養生シート内部温度の測定結果と考察}

気温が最も高くなる 12:30 13:30 の内部温度の変化に ついて，横置き試験箱の場合を Fig. 8 に，縦置き試験箱 の場合を Fig.9 に示す.

Fig.8 より,横置き試験箱において内部温度は黒が最も 高く, 次にグレーが高く, 白と白黒が最も低くなる。白 と白黒は内部温度に差がほとんど見られない.

Fig.9 より,縦置き試験箱においては横置き試験箱と近 い内部温度の変化を示したが，養生シートの色の違いに よる内部温度の差は小さくなり, 内部温度は高い順から 黒，グレー，白黒，白となる，縦置き試験箱の日射を受 ける面積が横置き試験箱より小さいため, 内部温度の差 が小さくなったと考える。白と白黒の内部温度に差が見 られるのは，Fig.10 に示すように表面と裏面の中間位置 近傍に色の境界を持つ養生シートが地面に垂直方向に 設置されていることから，斜入射した日射の一部が白黒 の養生シートの内側の黒部分に当たりやすくなったた めだと考える.

以上より，実現場では養生シートは地面に垂直方向に 設置されることを考えると，白黒の養生シートは黒，グ レーの養生シートより内部温度が低くなるが，白色の養 生シートより内部温度は高くなる。

\section{6 養生シートの透視性と内部空間の感じ方の測定}

\section{$6 \cdot 1$ 視力検査表を用いた透視性の測定結果と考察}

視力検査表を用いた透視性の測定結果を Fig.11 に示 す.Fig.11より，検査表(1)と検査表(2)においては透視性の 良い順番から白黒，黒，グレー，白となる．検査表(3)(4) (5)においては透視性の良いシートの順番に違いが見ら れるが，白黒はどの検査表においても透視性が良い。検 査表(5においては, LogMAR は対数であり, $\log M A R_{1}$ が 低いことから, LogMAR 低下值も他の検査表に比べて著 しく低い值となる。

次に養生シートの色による透視性の差の有意性を検 定するために，分散分析を行なった。結果，すべての検 査表の種類において，養生シートの色による透視性に危 険率 1\%で有意差が認められた。
Table3 Gender and age of subjects.

\begin{tabular}{|l|c|c|c|c|}
\hline \multirow{2}{*}{} & \multicolumn{2}{|c|}{$4 \cdot 2$} & \multicolumn{2}{c|}{$4 \cdot 3,4 \cdot 4$} \\
\cline { 2 - 5 } & Male & Female & Male & Female \\
\hline 20's & 3 & 3 & 3 & 3 \\
\hline 30 's & 3 & 4 & 3 & 3 \\
\hline 40 's & 3 & 3 & 2 & 4 \\
\hline 50 's & 6 & 3 & 5 & 2 \\
\hline 60 's & 4 & 1 & 3 & 1 \\
\hline \multirow{2}{*}{ Total } & 19 & 14 & 16 & 13 \\
\cline { 2 - 5 } & \multicolumn{3}{|c|}{33} & \multicolumn{2}{|c|}{29} \\
\hline
\end{tabular}

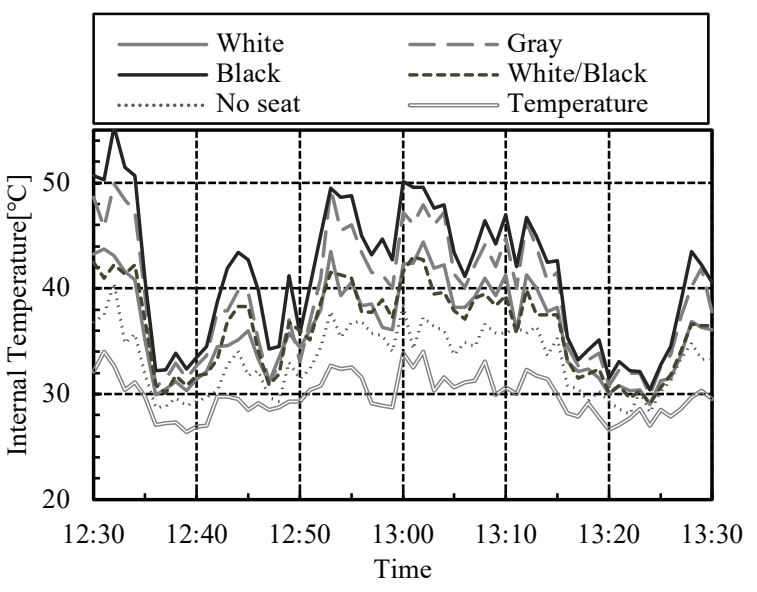

Fig.8 Relationships between internal temperature and time (Test box of placing it laterally).

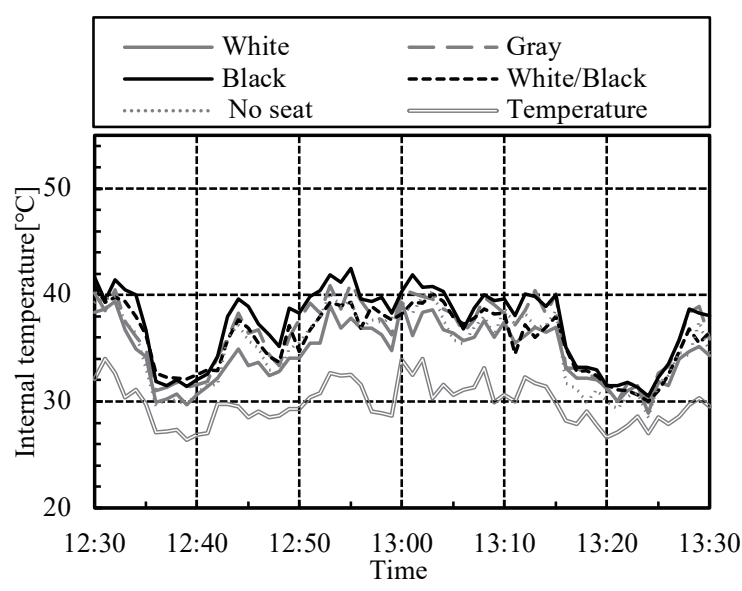

Fig.9 Relationships between internal temperature and time (Test box of placing it vertically).

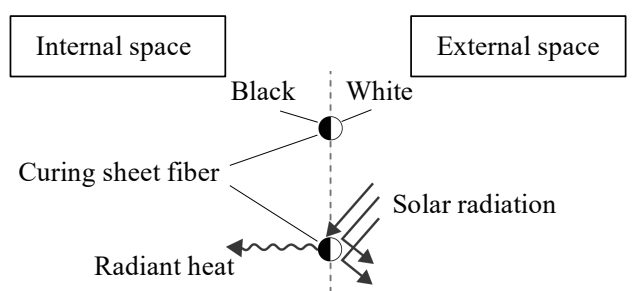

Fig.10 Image of solar radiation hitting the curing sheet.

\section{$6 \cdot 2$ 景観写真を用いた透視性の測定結果と考察}

人工景観写真を用いた透視性の測定結果を Fig.12 に, 自然景観写真を用いた透視性の測定結果を Fig.13に示す. Fig.12より, 各養生シートの色において, 人工景観写真 の「全体の見やすさ」,「左側のビルの見やすさ」,「空の 
見やすさ」の項目に大きな差は見られない.一方, Fig.13 より，白とグレーの養生シートにおいて，自然景観写真 の「下側の草木の見やすさ」は「全体の見やすさ」と「空 の見やすさ」の項目に比べ，評価が低い結果となった. これは，草木の輪郭がはっきりしてないことで，より見 にくいと判断したためと考える.

人工景観写真の「全体の見や寸さ」と自然景観写真の 「全体の見やすさ」を比較した結果を Fig.14 に示す.

Fig.14より, 各養生シートの色において, 人工景観写 真と自然景観写真の「全体の見やすさ」の平均值に大き な差が見られない。また人工景観写真と自然景観写真の どちらにおいても白黒，黒，グレー，白の順に見やすい 結果となった.

人工景観写真と自然景観写真それぞれにおいて, 養生 シートの色による「全体の見やすさ」の差の有意性を検 定するために，分散分析を行った。その結果，養生シー トの色による見やすさに危険率 $1 \%$ で有意差が認められ た。そこで，次に多重比較を行った。多重比較にはボン フェロー二補正を行った。多重比較の結果，黒と白黒以 外のすべての養生シートの組み合わせにおいて危険率 $1 \%$ で有意差が認められた。

以上より, 白黒の養生シートは黒の養生シートと同様 に透視性が良く，白，グレーの養生シートより透視性が 良い. ここで Table1より，白やグレーの養生シートは黒 や白黒の養生シートの黒部分と比べてマンセルバリュ 一の值が高い。このため, 白やグレーの養生シートは養 生シート内側の光が反射しやすく，黒と白黒の養生シー トの黒部分は反射しにくい，これにより，黒と白黒の養 生シートの黒部分のなす面から照射される光は養生シ 一ト外側からの光を多く含み，ノイズとなる反射光が少 なくなるため，白やグレーの養生シートに比べて透視性 が良くなったと考える。

\section{$6 \cdot 3$ 内部空間の感じ方の測定結果と考察}

内部空間の感じ方の測定結果を Fig.15 に示す. Fig.15 より,明るさ以外の項目で白黒は他の養生シートの色に 比べ養生シートなしの場合との差が小さい.よって，白 黒の養生シートは養生シートの設置前後で内部空間の 感じ方の変化が小さい.

次に養生シートの色による, 内部空間の感じ方の各項 目についての差の有意性を検定するために，分散分析を 行った. 分散分析の結果，〈開放感〉と〈明るさ〉の項目 において，養生シートの色によって危険率 $1 \%$ で有意差 が認められた。〈温冷感〉と〈快不快感〉の項目において は有意差が認められなかった。

\section{$6 \cdot 4$ 透視性と内部空間の感じ方の相関}

透視性の良さが内部空間の感じ方に与える影響を検 討するために，各被験者の人工景観の見やすさと自然景 観の見やすさの平均值と，内部空間の感じ方の相関を調 べた，開放感と見やすさの相関係数は 0.58 であり，開放 感と透視性には相関が見られる。また快不快感と見やす
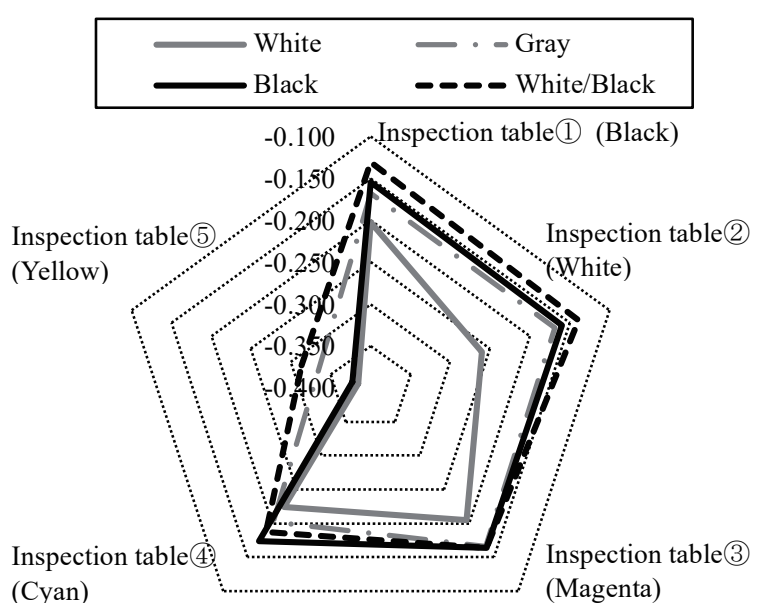

Fig.11 Decrease in LogMAR for each color of the curing sheet.

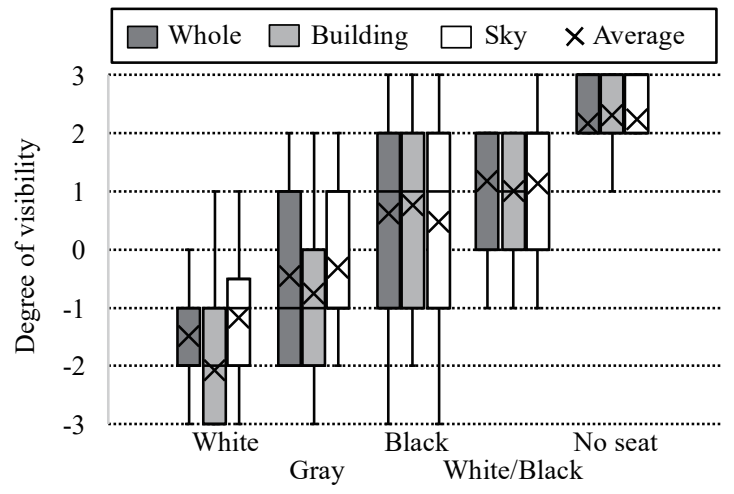

Fig.12 The degree of visibility of the artificial landscape photo for each color of the curing sheet.

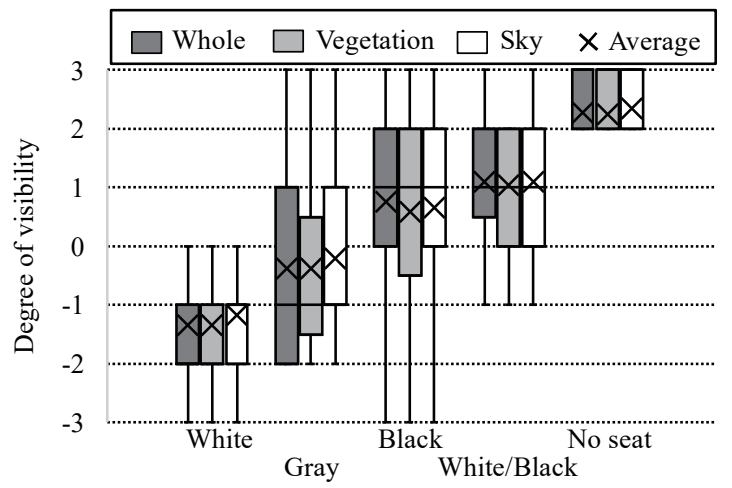

Fig.13 The degree of visibility of the natural landscape photo for each color of the curing sheet.

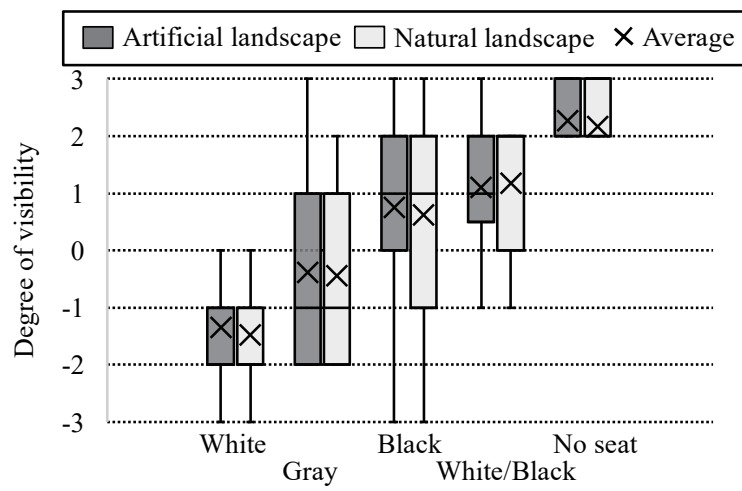

Fig.14 The degree of visibility of the whole landscape photos for each color of the curing sheet. 


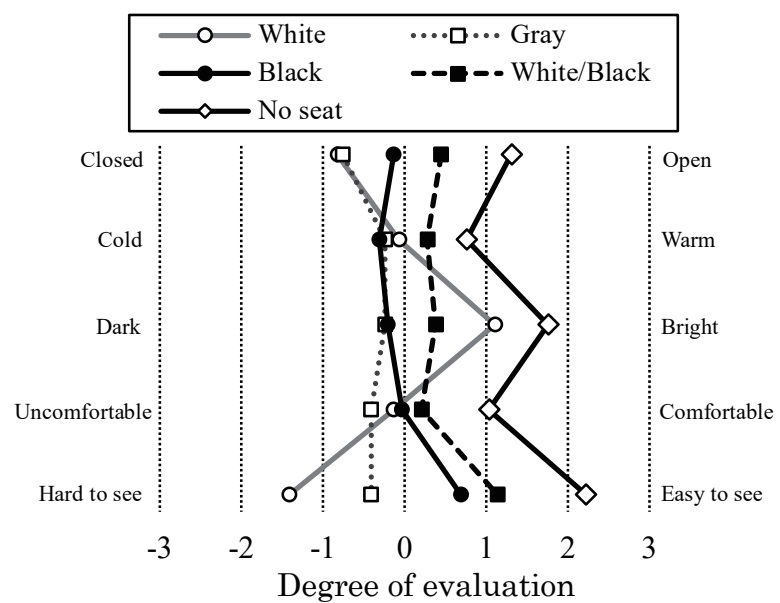

Fig.15 How to feel the internal space in each color of the curing sheet.

\section{さの相関係数は 0.51 であり, 快不快感と透視性には相関 が見られる。}

以上より，養生シートの透視性に対して内部空間の開 放感亡快不快感は相関があり，透視性が高くなると開放 的，快適と感じやすい。

\section{7 結 言}

本研究では，一般的に用いられる白色，グレー，黒色 の養生シートと，新たに製作した白黒の養生シートを使 用して, 内部温度の測定と, 透視性と内部空間の感じ方 の官能評価を行った．本研究の範囲内で以下の知見が得 られ，また白黒の養生シートを用いることで，従来の養 生シートを用いる場合に比べて養生シート内部からの 透視性を高めつつ，夏季の温度上昇を抑制する効果が得 られ，居住者の環境改善が行えることが期待できる.

1）白黒の養生シートは黒，グレーの養生シートより内 部温度が低くなるが，白色の養生シートよりは内部 温度は高くなる。

2）白黒の養生シートは黒の養生シートと同様に透視 性が良く，白，グレーの養生シートよりも透視性が 良い.

3）白黒の養生シートは養生シートの設置前後で内部 空間の感じ方の変化が小さい.

4）養生シートの透視性に対して内部空間の開放感と 快不快感は相関があり，透視性が高くなると開放的， 快適と感じやすい

本報の一部は，2020 年度日本建築学会東海支部研究 集会（愛知，令和 3 年 2 月）で発表した。また，2021 年 度日本建築学会大会（東海）学術講演会（愛知, 令和 3 年 9 月）で発表予定である.

\section{参 考 文 献}

1) Ministry of Land, Infrastructure, "Transport and Tourism, Number of condominium stocks: As of the end of 2019, July 1, 2019 update", https://www.mlit.go.jp/common/001351557.pdf (accessed 2020.11.13)

2) M.Tyatani, R.Nagashima, M.Ishida, K.Yagi, R. Oono and H.Nakamura, "A study on the effects of visual shield: No.1 the influence of the brightness on visibility", Summaries of Technical Papers of Annual Meeting of Architectural Institute of Japan, Vol.58, pp.1681-1682 (1983).

3) M.Tyatani, R.Nagashima, M.Ishida, K. Yagi, R.Oono and H.Nakamura, "A study on the effects of visual shield: No.2 the efficiency of visual shield", Summaries of Technical Papers of Annual Meeting of Architectural Institute of Japan, Vol. 58, pp.16831684 (1983)

4) K.Nakamura, N.Kubotani, S.Kobayashi, Y. Nakamura and M.Inui, "Window luminance-view relationships in an office: Part1 glare evaluation watching on a CRT screen and restraint of window luminance", Summaries of Technical Papers of Annual Meeting of Architectural Institute of Japan, Vol.1994, pp.1065-1066 (1994).

5) N.Kubotani, S.Kobayashi, Y.Nakamura and M.Inui, "Window luminance-view relationships in an office: Part2 see through control of window with window shadings", Summaries of Technical Papers of Annual Meeting of Architectural Institute of Japan, Vol.1994, pp.1067-1068 (1994).

6) N.Kanemura, S.Kawabe, Y.Ito, M.Urata, "The Effect of color and aluminum coating area of curing sheet on temperature of internal space", Proceedings of Tokai Chapter Architectural Research Meeting, Vol.58, pp.29-32 (2020).

7) Y.Murae, K.Mori, K.Oshima, K.Tuzuki, Y. Nabeshima, N.Okusi and T.Yamashita, "Study on effects of thermal environment and exercise intensity on physical workers Part 1 Outline of the subjective experiment on WBGT and exercise intensity with climatic chamber", Technical Papers of Annual Meeting the Society of Heating, Air-Conditioning and Sanitary Engineers of Japan, Vol.6, pp.309-312 (2018).

8) Y.Tanaka, K.Tanaka, S.Yokoyama, H.Nakamura, K.Ichikawa and S.Tanabe, "Development of a new testing system of color visual acuity and an example of examination outcome", The Institute of Image Electronics Engineers of Japan Magazine, Vol.41, No.5, pp.487-485 (2012).

9) Y.Nakamura, S.Kobayashi, M.Inui, T.Kondoh, M.Osawa, "The interrelation between a window screen's ability to lower luminance and it's ability to permit a clear view of outside scenery", Journal of Architecture and Planning Transaction of AIJ, Vol.484, pp.9-16 (1996).

10)M.Ishida, H.Nakamura, S.Ochiai, K.Takahashi, H.I to, "A study on the effects of visual environment with venetian blind", Summaries of Technical Pap ers of Annual Meeting Architectural Institute of $J$ apan. Architectural Planning and Design Rural Pl anning, Vol.1985, pp.333-334 (1985). 